\title{
Interruption as a crisis. Discourse and practices of progressive education
}

\section{Interrupção como uma crise. Discursos e práticas da educação progressiva.}

Martin Bittner ${ }^{1}$

\section{RESUMO}

A pedagogia Jena-Plan tem um impacto particular nas práticas educacionais nas escolas do século XXI. As práticas educacionais de escolarização e ensino nas escolas primárias alemãs são orientadas pela individualização, autoavaliação, posicionamento descentralizado do professor, tarefas de resolução de problemas e autorreflexão e, ao mesmo tempo, por uma estimativa de coletividade processada ao longo da aprendizagem entre pares e o ensaio da democracia. Essas várias práticas podem ser rastreadas até uma genealogia e às ideias da Educação Progressista do início do século XX. Embora posicionada como um discurso marginalizado no século XX, a Educação Progressista hoje em dia pode ser vista como a resposta para os problemas sociais atuais e espera-se que corresponda bem aos desafios reais da escola. A instituição enfrenta diversidade de contextos culturais e sociais de seus alunos, e expectativas de chances justas e iguais de aprendizado em um mundo globalizado, e, portanto, competitivo e marcado. $\mathrm{O}$ artigo apresenta trechos de um estudo etnográfico de uma escola primária sócio problemática do centro da cidade, onde o conceito e as ideias da Educação Progressista e, em particular, de Peter Petersen foram renovados para abrir possibilidades de aprendizagem, educação e Bildung em toda a instituição.

Palavras-chave: etnografia institucional; práticas educacionais; transformação da escolarização.

\begin{abstract}
Jena-Plan pedagogy has a particular impact on the educational practices in schools of the $21^{\text {st }}$ century. Educational practices of schooling and teachings in German primary schools are driven by individualization, selfassessment, decentralized positioning of the teacher, problem-solving tasks and self-reflection, and at the same time by an estimation of collectivity processed throughout peer learning and the rehearsal of democracy. These various practices can be traced back to a genealogy and ideas of Progressive Education of the early $20^{\text {th }}$ century. While positioned as a marginalized discourse in the $20^{\text {th }}$ century Progressive Education nowadays can be seen as the answer for current social problems and is expected to correspond well with the actual challenges of the school. The institution faces diversity of cultural and social backgrounds of their pupils and expectations of just and equal chances of learning within a globalized and thus competitive and marked driven world. The article presents extracts of an ethnographic study of a so called socio-problematic, inner-city primary school where the concept and ideas of Progressive Education and in particular of Peter Petersen have been renewed to open up possibilities of learning, education and Bildung throughout the institution.
\end{abstract}

Keywords: institutional ethnography; educational practices; transformation of schooling.

\footnotetext{
${ }^{1}$ EUF - Europa-Universitaet Flensburg, Flensburg - Germany.
} 


\section{INTRODUCTION}

Participants of schooling are challenged to construct a social order in the classroom that provides possibilities of learning and self-education. Following the instruction of the teacher and adapting school-smart knowledge to perform learning are the most common perspectives on classroom teachings. These interpretations of the social order in a classroom are also joined with a perspective on disciplining pupils through evaluation processes even by physical or mental punishment, a loose of appreciation, or positioning them in relation to a value-system of marks. In this paper I will focus on the questions: How does the shared practices of teachings construct a social order of learning? What is the impact of Jena-Plan pedagogy to solve a crisis and ensure the social ordering in the classroom?

In the first section I will give an introduction into the educational concept of Peter Petersen and will outline the role of Progressive Education (Reformpädagogik) in general and of the Jena-Plan in particular in the discourses on school-pedagogy. The reconstruction this paper is based on is organized towards an ethnography of practices and an analysis of discourse. I will argue for an ethnography that uses video recordings and participant observation as an appropriate method to observe and describe practices and discourses of institutions. The field under study is a primary school in Germany. The characteristic especially for schools following progressive education is a setting of simultaneity of practices. Thus, videography can be seen as an appropriate approach to capture and gather practices and to describe a general social order. In the main part of the article I will present results from the methodological approach and give insights into an interpretation of an arts-lesson. The chosen example will also answer the above raised questions on processes of learning and its interruptions.

\section{THE DISCOURSE ON PROGRESSIVE EDUCATION}

The term Progressive Education subsumes different ideas, concepts and postulations on education which became famous by the dawn of the twentieth century and are part of the educational discourse nowadays. The various standpoints are to some extend opposed to each other as they do relate to different levels, i.e. the organizational, the political, the social, the pedagogical perspective etc. Since the public school system emerged, Progressive Education gave an answer to a prominent criticism on the forms of child rearing and classroom instruction (Reese, 2001).

In its beginning in the end of the $19^{\text {th }}$ century and beginning of $20^{\text {th }}$ century the Progressive Education raises the voice for pedagogical change. Progressive Educationalists followed particular discourses on learning proposed by the emerging discipline of psychology of the child those days (for example William Stern, Berthold Otto and more importantly Ellen Key, Stanley Hall, Maria Montessori). The main concern was related to common didactics (of Johann Friedrich Herbart). The practices of schooling were perceived as didactic materialism or mechanistic didacticism that had placed too much emphasis on children's possession of factual knowledge and the memorization of material (Lamberti, 2000, p. 32). Progressive Educationalists aimed to change teaching methods and by this challenged the fundamental ideas of learning as memorized knowing. Knowing the subject which has to be taught and demanding for a person's discipline had been esteemed as an one-dimensional way of teaching. In opposite to that, progressive thinkers expand the idea that learning has to be related to the life of the learner and the future life in (a democratic) society. In doing so they stressed self-expression and the individual development of the learner to be important. Ideas of child-centered and active-learning teachings as well as a democratic school reforms establish the basis for these new pedagogies 
(examples of representatives are Alfred Lichtwark, Alexander S. Neill, Georg Kerschtensteiner, Hermann Lietz, Maria Montessori, John Dewey and Peter Petersen).

The upcoming of the Progressive Education movement in Germany can be seen in relation to the ideas of the US-American thinkers in particular John Dewey and the influence of the development in the field of education and psychology in the US that encouraged the progressive movement in Germany and brought the discourse to prominence. While Peter Petersen an educational thinker from Germany to whom I will refer later, have had visited John Dewey in 1928 and was very much inspired by him, John Dewey had not had any interest in the pedagogical concepts of Petersen (Retter, 2009). Deweys position was orientated on the change of school system and society and thus was about a greater change of education, while German Progressive Education was concentrated on the particular pedagogy. Progressive Pedagogy finds its autonomous roots within German romanticism as well as enlightenment. The emergence of Progressive Education in Germany was accompanied by a youth movement which promoted personal freedom and refused the fossilizing industrialization and fostered a post-romantic reminiscence of the human being in nature and not only an intellectual and reason of the state criticism of teaching.

Even though we can find similarities between the emerging of Progressive Thinking in Germany and in the US, we still have to distinguish these practices from the program which is generally translated as "Progressive Education". Lamberti (2000, p. 23) states: "The dissemination of the theories and practices of Progressive Education within the public school teaching profession in Germany has not been carefully researched." The main impact of the German Progressive Education was on a more practical level. To the pedagogical and practical extend of Progressive Education and the European history those ideas had been combined under the term "reform pedagogy" (Reformpädagogik).

Teachers who followed and developed the ideas of reform pedagogy like those who followed the ideas of Progressive Education did criticize the social institutions, injustices and privileges of a minority as well as the disparity between different types of schooling (in Germany that is Volksschule (grade school) and Gymnasium (grammar school)). Although there had been some similarities in the critic of industrialization and the idea of democratization, the reactions and responses went into a practices of pedagogy, while others went into the reform of the educational system.

Thus the idea of Progressive Education was related to the in those days contemporary situation of economic and social development, i.e. social justices and equality and became a top-down process of institutionalized critic and change, though reform pedagogy in addition became a button-up process and transferred the idea of education for all into an understanding of learning and self-education of the child through practices of teaching which can be seen in relation to the individual needs of the person. "Whereas Dewey defined educational purpose in terms of the individual's integration into a modern society, the Europeans laid greater stress on 'self-realization' and the inner growth of the individual" (Jones, 1983, p. 29).

\section{Peter Petersen an early representative of reform pedagogy}

Peter Petersen (1884-1952) is one of the representatives of reform pedagogy|Progressive Education of those days. His concept of schooling became famous in different countries and also influences the investigated school. Petersen was instructed by the ministry of education to establish a training program for teachers as well as a comprehensive school. From 1923 onwards, Petersen developed a 
school-concept that was later called "Jena-Plan". ${ }^{2}$ Petersen established mixed age learning groups instead of groups of homogeneous age, he integrated coeducation into the school, he developed a broader concept of community building, i.e. the school became the center of living for the child and his family, and formulated a different meaning of teaching, that is to educate the child and to enable an individual-mental development through self-regulation for the child. He integrated the ideas of Pestalozzi and Fröbel to build up this new education (Petersen, 1927/1980). To develop the concept but also to educate children in an appropriate way he did factual-oriented research (Tatsachenforschung).

Following Petersen (1963) the practices of schooling are orientated to an understanding of education that is based on four archetypes of learning: conversation (i.e. circle talk, reports, presentations, debates, etc.), play (free play, learning games, theatre, sport games, etc.), work (solitaire, pairs, groups, etc.), celebration (birthday, school enrolment, farewell, etc.). The learning type of celebration has no relevance in the observed situation. It goes along with specific forms of ritual based transformations for the individual or course of the school year. Also the approach of work is not in focus for this example. Work describes particular ways of teaching and learning and although there are differences to Johann Friedrich Herbarts conception of learning (Herbartianism), it still follows some ideas of a structured curriculum. Thus, we can consider the types of play and conversation to be from innovative relevance for the understanding and perception of schooling and will be elaborated in the following two paragraphs.

Play is described as the natural action of a child. That is why in a child-centered pedagogy play has to be integrated into the practices of teachings. Play is supposed to take place everywhere, it is expected to teach the child, it is about practicing and guidance to develop skills and competences. Play takes an important role in the pedagogy of Petersen as it also motivates the child to learn and interact.

Conversation is for Petersen a general issue of everyday life, which has to be practiced and leads to learning. Besides work it is seen as the most important impact on the practices of schooling in this school. Through conversations the child and the teacher are recognized as subjects in the social situation but also as individuals. ${ }^{3}$ Conversation is not only seen as a given form of communication practices but also as a knowledge which has to be practiced, repeated and transformed.

Petersen integrates and presents the four types of learning as a basic understanding for his pedagogy. Furthermore these basic types of learning can be seen as the pre-pedagogical conditions of the human and thus can be linked to an anthropological continuity of education and an expression of culture that needs to be approached through ethnography (Wulf et al., 2010).

\footnotetext{
2 Following the US Tradition of labeling educational concepts to their geographical location Peter Petersens concept of Progressive Education became known as the "Jena-Plan" due to the fact that he during that time holds a position as a Professor for educational sciences at the University of Jena, Germnay. Other prominent education plans that can be compared with the Jena-Plan are for example the Dalton-Plan and Winnetka-Plan in the Anglo-Saxon world.
}

3 The question of recognition and estimation as specific emotional practice of this school has been elaborated in Wulf et al., 2012. 


\section{Information on the field}

The school under research has beard the name Peter Petersen for years. The $100^{\text {th }}$ anniversary of Petersen in 1984 gave the first impulse for the principle and the teachers to fathom his ideas. The school started to elaborate a concept based on the ideas of reform pedagogy in general and on the concept of Peter Petersens Jena-Plan in particular. It was in 1994 when the school started a laboratory school. Together with the external support of educational scientists, the principal and her colleagues implemented and adjusted the pedagogy of Peter Petersen into their school. Already at that time but also in the following years the district in which the school is located became a problematic area in terms of its socio-economic situation. ${ }^{4}$ The socio-cultural background of the pupils challenge the teachers not only to teach the children but also educate and equip them with equal chances. Thus we can see similarities to the struggling past of the birth of Progressive Education. Educational aims need to be related to the social and economic development not only in the beginning of the twentieth century but also in its end. In the beginning twenty-first century the practices of reform pedagogy are prominent in most primary schools and had been implemented widely. Pupils in these schools are organized in mixed-age learning groups (family-groups) and are addressed by multi-methodical composition of teachings. Characteristics instead of marks, and evaluation processes that support concepts of recognition and estimation and do not reduce and force the pupils to reproduce the correct content of the school-curriculum (Wulf et al., 2012). Progressive Education builds on the insight that teaching has to take place in an open learning atmosphere, which means to change the rhythm of time and the practices of teachings into self-regulated teaching, evaluation processes are aimed to give individual feedback in relation to the competences and skills of the individual pupil. Peter Petersens progressive approach by this seems more relevant at its present stage than ever before. This perspective of the panacea Progressive Education for the current societal challenges of learning, education and Bildung needs to be confronted by its practical and discursive relations.

\section{METHODOLOGY BY FIELD}

Peter Petersen together with his wife Else Müller-Petersen and their colleges developed a method of research to show the (psychological) impact of the teaching practices of the Jena-Plan. They in particular developed the approach of factual-orientate|documentary research (Tatsachenforschung). This pedagogical research (pädagogische Tatsachenforschung) can be situated between an ethnographic approach of participant observation in the school and experimental psychology of measuring and quantification of particular facts that relate to the understanding of education. The method at hand allowed to gain an understanding of what was going on in the classroom (MüllerPetersen, 1951, 1965). Contrary to a social theoretical or even anthropological approach following any theory of knowledge, Petersens approach aimed not only to describe but to reconfigure the teaching in relation to the (observed and analyzed) needs of the learner/pupil. Tatsachenforschung by this became a practice of reflexivity for the practitioner|the teacher to open up possibilities of action that will enable the pupil to re-act.

In this article I will not stress the Tatsachenforschung but aim to ethnographically describe the practices and discourses of current Jena-Plan Education. Although Tatsachenforschung has defined educational sciences in the beginning, this method of pedagogical practice need to find its way back into the research of educational settings. The approached educational ethnography aims to describe

\footnotetext{
${ }^{4}$ Since 1999 it takes part in a federal program on urban development to work against the social-special rifts of the city.
} 
the pedagogical practices and discourses and its social ordering that needs to be understood by the arrangements processed by the pupils and their teachers. Tatsachenforschung in its approach of reflexivity exposes the teacher of not being part of the educational arrangement in the institution, while ethnography aims to grasp the particular entity of education settings.

\section{Among Practices and Discourses}

Reform pedagogy presents its own governmentality, as it has formed an ensemble of procedures and tactics to ensure an apparatus of security, i.e. first, reform pedagogy formulates an answer to social problems like inequality, second, reform pedagogy has developed a complex of knowledge and practices (of knowing how, also in the sense of the French "savoir") and third, reform pedagogy reviews a process of history and transformation of itself (Foucault, 1991a, 102ff.). The practices of classroom teachings are ruled by this governmentality. That is why the impact of Progressive Education on the practices of teachings has to be described and the progressiveness, the reformative of the observed practices of teachings have to be reconstructed.

By following Schatzkis definition on practices as a "temporally evolving, open-ended set of doings and sayings linked by practical understandings, rules, teleoaffective structure, and general understanding" (Schatzki, 2002, p. 87) we have a heuristic at hand while reconstructing the order of the social. The definition poses a challenge to interpret the different dimensions of practices. Schatzki is distinguishing his understanding of practice to the understanding of discourse as Laclau and Mouffe or Wittgenstein are grasping it. The understanding of a practice is accompanied by practical intelligibility. It is about a bodily, corporal, performative experiential, implicit knowledge based on shared experiences and explicit rules which does not have to be reformulated in every situation. This nexus of doings and sayings (Schatzki) enables the subject to enact in an appropriate way. This is not only an expression of what to do but also on how to act. "Participating in a practice is operating in an arena where certain actions and ends are prescribed, correct, or acceptable on certain occasions" (Schatzki, 2002, p. 75). Focusing on practices in this understanding means to outline an understanding of the social order. From my perspective, this is also related to discourses as we have already seen that the practices of Jena-Plan schooling have a long tradition and had been in charge of research for a long time. While for Schatzki the discourse is something highly similar to the social order, but it is the practice which constitutes the social order, it is for Laclau/Mouffe about the discourse which constitutes the social order and thus practices are forced by discourses and lead to discourse - but their role in the social theory is less important than the discourses itself. With Schatzki (and also with Bourdieu) this perspective of the hegemony of the discourse is rejected by the perspective of the power of the practice. I argue that discourse is not solely meant in terms of language and communication but language "is itself a social practice that integrally involves a rich practical and perceptual engagement with our surroundings. Indeed, language use itself involves complex bodily skills" (Rouse, 2007, p. 515). Thus there is a relation between practice and discourse which has been discussed widely by practice theorists. Some argue that it is about the practice which constitutes the social order and has its power. Different terms are in use here: practical intelligibility (Schatzki), habitus (Bourdieu), while others argue for the discourse to structure the social practices (Foucault, 1972, p. 131): "Lastly, what we have called 'discursive practice' can now be defined more precisely. [...] it is a body of anonymous, historical rules, always determined in the time and space that have defined a given period, and for a given social, economic, geographical, or linguistic area, the conditions of operation of the enunciative function". 
For Foucault practices "are not just governed by institutions, prescribed by ideologies, guided by pragmatic circumstances [...] but possess up to a point their own specific regularities, logic, strategy, self-evidences and 'reasons'" (Foucault, 1991c, p. 75). Foucaults understanding of discourses as a regime of practices can be related to Schatzkis understanding of the social as for both the set of rules, strategies and the order of things play an important role. To study the ensembles of discourse for Foucault means to characterize them by defining the play of rules, of transformations, of thresholds and of remanences (Foucault, 1991b). "Discourse is not a place into which the subjectivity irrupts; it is a space of differentiated subject-positions and subject-functions" (Foucault, 1991b, p. 58). The reconstruction of practice though is always a reconstruction of a enunciative system of practices.

\section{Videography: A methodological approach on practices and discourses}

Videography has the potential to capture these doings and sayings empirically, while the teleoaffective structure and the discourse of a practice has to be reconstructed on an implicit level of how practices are performed.

Thus, the reconstruction has to be carried out on different layers of analysis and interpretation. If we assume an interrelation between discourses and practices, that is expressed, performed and rehearsed in the everyday of schooling, we need to reconstruct through a method in consideration to a logic of practice (Bohnsack, 2007; Bourdieu, 1976). ${ }^{5}$ The reconstruction of common practices of a social order can be realized by an accumulation of similarities as well as by focusing on the disruptions and contradictions in a social situation. Videography allows this approach.

The study, which has been realized between 2010 and 2013, is an ethnographic study of a mixed age learning group with boys and girls at the age of 9 to 12 years. The data was conducted in a JenaPlan School, that is practicing the ideas of the reform pedagogic thinker "Peter Petersen".

The strategy of focused ethnography has been undertaken with regard to a socially and culturally highly differentiated and fragmented society, where activities and practices are specialized. Focused ethnography as "a peculiar form of ethnography, [...] is characterised by relatively short-term field visits" (Knoblauch, 2005, 2). Within three months in 2010 and several short time visits in the years 2009 to 2012 a processes of participant observation and audiovisual data collection was accomplished, followed by an intensive two years of data-analysis. The interest of this study on the practices within the classroom and its relation to the school as an institution. By this I do accept the practice turn in contemporary social theory and claim that practices are the first and smallest unity within cultural analysis (Reckwitz, 2002). The everyday practices of schooling had been observed and video-recorded. The video-data which was constructed here can be seen as a representation of the social practices in the field of education.

In the following I will argue for Videography as a strategy within focused ethnography that gives consideration to the complexity of the social order. Videography can be defined in its methodological approach between ethnography and cultural analysis. The video-recordings enable the researcher to grasp the complexity of a social order, as it on the one hand underlines what has become accepted as performativity (at first Victor Turner as well as John Austin) and rejects on the other hand the

\footnotetext{
${ }^{5}$ Please see Bohnsack et al., 2010 for first English texts on the methodological approach of documentary method.
} 
crisis of representation (Clifford \& Marcus, 1986). Videography takes into consideration not only the sequentiality of the social, but also the co-temporality or simultaneity of a situation. The video facilitates us to reconstruct, how social practices are accomplished in their contemporary contextualization. "While the basic model of sequentiality is a successively ordered text, the basic model of simultaneity is a picture" (Wagner-Willi, 2006, p. 144). The possibility of repeated viewing, frame-analysis, the comparison between slow and fast motion, the transcript of (non)verbal expressions allows us to analyze details that are not perceivable through participant observation. If we take practice theory as a possible frame to analyze the social order, the interest of the investigation lies on this micro-level of social performance (Reckwitz, 2002, 2003). Videography provides the researcher with data by which the micro-level of the social can be conducted. By this the logic of the practice, the mise-en-scène as a way of sense making in a social situation can be shown.

Through practice theory an anthropological perception of the micro-level of the social is intended. Thus, ethnography as a scientific method to capture the practices of the social order play an important role on the perception of the practices and thus follow a discursiveness. Here the interpretation and reconstruction of the video-data becomes important.

\section{THE PRACTICES OF PROGRESSIVE EDUCATION ${ }^{6}$}

In the following paragraph an empirical example will be described, analyzed and interpreted. It provides insights of an introduction during an arts-class. In the situation of teachings pupils and the teacher have to ensure the practices of play and of conversation.

The adjusted archetypes of learning, a shared experience of everyday life interaction gives the framework to the situation of teachings. The following disorder in the situation will turn the shared practices and their discourses to an explicit elaboration.

\section{Between conversation and play}

Prologue: [Friday morning, on the class schedule for the mixed age learning group arts is compulsory. Pupils are sitting in two rows of tables vertical two the teachers desk in the room of Mr. Meyer, who is the teacher for arts. Mr. Meyer (MM) is projecting a picture on the wall, but he hasn't focused the overhead projector, the image what can be seen on the wall is only shadows of color. Most of the pupils have turned their heads in direction of the wall, where the image is screened.] $]^{7}$ ((The presentation of the image is accompanied by different comments from some pupils.) $)^{8}$

(What=s that?)

(This looks silly.)

(How focused.)

(Is the picture like this?)

(A focused picture an unfocused picture.)

\footnotetext{
${ }^{6}$ This example has first been presented at a Symposium in Brno, Czech Republic in 2012. The given interpretation and focus on the empirical example in this article is different to the analysis and theoretical ideas published in Bittner, 2015 (my PhD Thesis in German).

7 Descriptions of the situation, bodily expressions and gestures are summarized in squared brackets to grasp the simultaneity of the situation. The representation of a picture and a pre-iconographic description like Panofsky is conceptualizing it, might be of some help argues Wagner-Willi (2006, p. 150).

8 Sounds or noises and audible contributions which are not clear will be given in double parenthesis. If a contribution cannot be attributed to a single person and if more than one person is speaking at the same time, everything audible will be presented in single parenthesis.
} 
[The teacher positions himself in front of one row of banks and is turning his head in direction of the pupils. Emre $(\mathrm{Em})$ and Bodo $(\mathrm{Bm})$ start to raise their hands.]

MM: can you see something or can you see nothing?

((Several pupils start to talk at once.)) [Bm, Em and Denise (Df) are raising hands.]

Gf: (nothing)

Am: (still you can see something)

MM: Bodo

Bm: Brown, green, red.

MM: A little louder please.

Bm: Red.

MM: Yes.

$\mathrm{Bm}$ : Maybe yellow also and white. [While Bm describes what he sees, MM is turning his head alternating in direction of $\mathrm{Bm}$ and the picture on the wall.]

MM: All right, please. [MM is pointing in direction of John (Jm)]

Jm: Over there the orange thing looks like a window.

MM: Okay. [MM is turning his back in direction to the pupils and is searching for something on his desk. While this Zlatko (Zm) get up from his chair and sneaks of to the overhead projector to get a glance of the original picture on the plate. MM is turning around. MM freezes in his motion of turning around, with a depth glance and by shaking his head, he talks to Zlatko.]

MM: Are you a play-spoiler? Isn't it?

Zm: (hushed and sneer saying "no")

Mr. Meyer (MM) is preparing some objects for the arts-lesson, which has generally started. As if in an open everyday atmosphere (in front of the school, during lunch-break) the pupils are talking to each other or just non-directional into the classroom - the question of on pupil remains with no direct answer. The pupils express their experience of irritation, by asking for what has been presented by the teacher on the wall. They recognize the unfocused scheme of light as a picture, thus they are relating it to their knowledge of space, time and subject. Another voice is audible evaluating what can be seen as "silly". Even though this is not an official category of evaluation - the speaker approximates himself to the group of pupils and peers. While the blackboard area and the wall as well as the projection of an object by the teacher can be expected as something serious in the setting of schooling the pupils realize the difference and express this by describing the presented picture as (un)focused picture. While they express the uncommon usage of the overhead-projector they do refer to an expectation and technical knowledge. Thus the following beginning of an teaching phase is accompanied by a contradiction. While the teacher positions himself in front of the rows, by raising hands, Emre (Em) and Bodo (Bm) show their understanding of the situation that has to follow the common rules of schooling. In general, in every conversation the pupils are obliged to raise their hands in case they want to say something. By raising hands, the students become visible for the teacher. Raising hands becomes a practice in schooling as it can be seen in direct relation to the evaluation process every pupil will be subjected to.

The teacher starts the teaching phase with a question which bears in mind the contradiction. This question is not at all a matter of factual knowledge, but introduces a conversation for this teaching phase. Still the question demands the pupils to adapt their performed answer to the practices of artsteachings.

Gina (Gf) and Ali (Am) who are sitting next to the camera and are audible because of that, again give antithetic understanding of what is going on. Bodo, who by raising hands performs the practice of conversation is called by Mr. Meyer. This finally demonstrates the forthcoming mode of conversation, which is an open structured collection of interpretations. Bodos analysis of what can be seen are colors, is related to a relevant knowledge of art by the teacher as he asks him to speak a little louder. By asking John to present his interpretation, Mr. Meyer implicitly expresses that at minimum a second 
answer is possible. He is promoting the modus of conversation in this situation as he is responding to the pupils answers with a common compliance of conversation (yes; okay).

By the circumstance that Zlatko $(\mathrm{Zm})$ is getting up and sneaking to the overhead projector while the teacher has turned his eyes off from the pupils, we got to know that different practices and understandings are present. There are a lot of open classroom situations the pupils are allowed to walk around and have a look on the desks of others, even talk to them, ask for help etc. In this situation getting up can be seen as an objection to present rules, which will be explicit in the moment Mr. Meyer detects him. Still Zlatkos acting signifies the contradiction to a present teaching phase. Zlatko highlights that, to know how the original picture looks like, could give him some benefit in the situation of teachings, that is either in reference to the teacher and/or to his position in the peergroup.

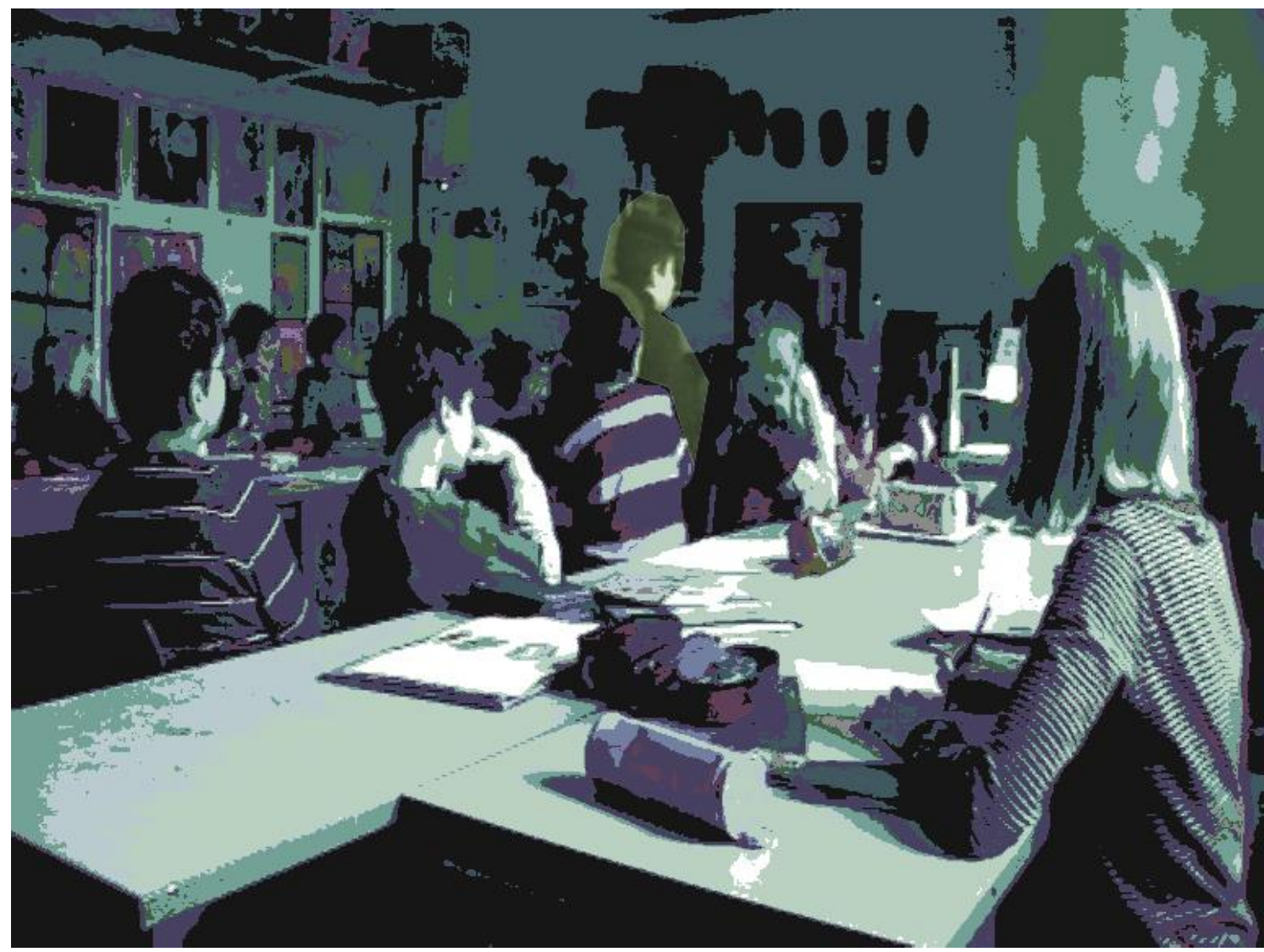

Picture: It is the dark light in the room, the spotted attention in direction of the projectors screening and its only light that "allows" Zlatko to stand up, being dressed all black and walk nearly unseen in direction of the projector. His peer students do not even notice him or at least not paying attention to his positioning in the classroom during this teaching phase.

The teacher is responding to this action with a question, but already his bodily expression underlines the following critic. While addressing Zlatko as a play-spoiler (Spielverderber) he points to the defiance of the practices of play. As we have figured out that in the conversation it might have been to some benefit for Zlatko to know the picture, in the very moment Mr. Meyer is constructing the teaching phase as a play, he excludes Zlatko from this play. The teleoaffectivity of the situation had been explicitly marked in this moment. The teacher thus follows a discursive practice, as play is recommended to motivate the pupils to learn. By asking Zlatko for self-reflection on his action (Isn't it?), Mr. Meyer follows another practice in this school -- self-reflection is a frequent practice, where the pupils choose a (social or learning) competence they want to work on for a period. Zlatko already 
in the beginning of the day had a conflict with Mr. Meyer who send him outside of the room for some time.

Through Zlatkos action the participants are confronted with a different understanding that composes a crisis of the social order and a resistance against the subjection which takes place in this playful conversation. A play is something which can be an expected as a practice for a child, while the selfunderstanding is orientated on being youth as the word "silly" would be assumed. An experience which is different to other teachers, a resistance against a subjection as a child. and provokes a crisis on the practices, which has some relevance to other students as Ali is after a while and more in direction to the camera saying that the teaching is "as always embarrassing".

What we can figure out here is a playful introduction into a topic of arts which is in crisis. It is about building up the attention for the topic and the lesson itself. The introduction can also be seen as a ritualized practice. I have observed different cases where in the moment the pupils are loud, unsettled and excited the teacher starts a lesson by playing a game.

Thus we can expect play and conversation to have a practical intelligibility to all participants. A ritual where conversation is in the center of practical order, the students are loud and unsettled, they do not follow the rules of conversation and don't pay attention to each other. One could expect the teacher to discipline them, while the teacher made the decision to play a game. The play will be continued and further developed in the next sequence.

\section{Between play and conversation}

Mr. Meyer has taken four pages of plain paper and has shadowed the picture on the plate. He then focusses the overhead projector. A sharply small cut-out of the image can be seen on the wall. Denise (Df) is the first pupil who raises her hand. MM walks in her direction, simpering.]

MM: Denise.

Df: I can see a tiny forest, a field and a white path

MM: A field and a white path? [MM gets closer to Df, his head is adjusted to Denise who is sitting on a chair, while MM is staying in the class.]

Df: Yes.

MM: All right. Is this running backwards? [MM is turning his head alternating in direction of Df and the picture on the wall.]

Df: Yes.

MM: You mean that, right. Interesting. It goes around the corner. [MM is walking backwards, while he is saying "interesting" he looks at Df with big eyes.]

Df: Yes.

MM: As a turned around "L", can you see that?

((Most pupils say "yes".)

MM: Well, thus it could be a landscape? [MM is walking around watching at a couple of pupils one hand on his chin and the other one on his hip.]

((Most pupils do agree with this again.))

Fm: (or a labyrinth)

MM: (a labyrinth) [Mr. Meyer changes and widens the projected cut-out.]

Gf: (I guess it's a window)

Zm: (I have seen a vase or something alike.)

MM: Yes. What have you seen? Well but you had been cheating, thus for you the fun is gone but the others they should just go bonkers. [MM is turning his head a sight and crosses his arms in front of his body.]

Mr. Meyer continues with the play and the pupils show that they share the practice. It is a play about ideas and imagination as well as a conversation. The questions by Mr. Meyer and the answers by the 
pupils produce a shared knowledge. A landscape or a labyrinth are the shared experiences of the current cut-out. While Mr. Meyer is preparing the next cut-out the pupils are again talking to each other or non-directional into the classroom about what can be seen. Zlatko is also saying something into the classroom. Mr. Meyer who was still preparing the next cut-out takes the stance and formulates a question. It is just in the moment that he recognizes that Zlatko is the one who has given the next answer that he is again highlighting what the aim of the play was - that is to weave a web of imaginations. He is again disciplining him for not following the shared practice like the others do. Again the practice which has to be performed has not expended its intelligibility to Zlatko. He directs the crisis to Zlatko by explicitly referring to the teleoaffectivity of the practice, which is to experience the introduction into a new topic as "fun". In the playful conversation it is not the factual knowledge but the community and the subject in the center of teachings.

Epilogue: [The teacher continues with the play of giving a framed cut-out of the projected image and letting the pupils imagine what it could be. Besides very common ideas of what it could be, there are some more unlikely visions (i.e. a nuclear power station) of what could be seen here. Mr. Meyer then presents the whole picture which is a seventeenth century still life (fruits, vases and boxes on a table). He plays another game with the students which is about memorizing what can be seen on the picture. After this he is introducing the next task of arts-class, which is related to the topic of shadows and the three-dimensional representations of everyday objects on a twodimensional level.]

The shadows in the beginning of the presentation, the cut-out to ask the pupils for their commonsense understanding and interpretation of objects is the playful representation of knowledge which is connected to the students next (learning) task in arts-class.

I have seen this open kind of conversation and play as an introduction to a theme to be taught many times in this school. But we could also see in the case of Zlatko that the child-centered practices of teaching, orientated on the understanding of the pupils and their particular Lebenswelt is not meaningful for every pupil. The crisis of the social order is transformed into a crisis of the subject to reproduce the valid and shared practices.

\section{DISCUSSION: LEARNING THROUGH CRISIS'}

In the situation of a crisis the practical intelligibility will be at risk and the shared understanding has to be inverted to an explicit knowledge of a practice. Thus to focus on contradictions and disruptions of a situation enables the researcher to elaborate the discourse of a practices, which brings order into the site of the social. A crisis carries the conditions for transitions and transformations but can also evoke the repetition or preservation of a practice. The situation of crisis is comparable to a practice formed by rules, understanding and teleoaffectivity, it is a bodily, emotional, spoken expression, which has to be answered on a practical level of the discourse.

In the example above we have seen a crisis in the practices of teachings forced by a single pupil, which was then covered by a modern psychological practice of self-reflection. Michel Foucault (1988) has described this care of the self as a modern expectation of the subject. I will not stress the crisis in detail but will refer to the broader question of the crisis of education as Hannah Arendt is claiming it. She says: "A crisis forces us back to the questions themselves and requires from us either new or old answers, but in any case direct judgements." A crisis is not only about the concrete situation but 
represents a general problem. From the position of pedagogical fact-oriented research (Tatsachenforschung), which we stressed earlier to be a certain reflexivity to be performed by the teacher, we might first of all ask, how the teacher experiences and performs this crisis. This will lead us to a greater understanding of a crisis within educational institutions.

For Arendt terms of crisis are very much related to a political level of the education system, as she asks for the reproduction of the new for the society. Still Arendt's understanding of crisis can be related to schooling as "school in a sense represents the world, although it is not yet actually the world" (Arendt, 1968, p. 9). While Arendt (1968) talking about the Crisis in Education in America, she explains that education plays an important role in this country, the political issues which are related to the education system in America remain also to other countries. America as the land of immigrants is always on the way to something new. I will not discuss the political role of education here but we should take into account that Progressive Education is not only about teaching practices but also about questions of society.

The crisis in the present example has to do with different understandings of teaching and learning and the struggling of subjection. Under the influence of modern psychology, pedagogy has developed into a science of teaching in general with less relation to the factual knowledge, which has to be taught (see for a critique and analysis of learnification Gert Biestas work). Arendt also sees a crisis because of the autonomy of the world of childhood (which had been elaborated by the progressive thinkers) and the herewith understanding of learning as anything through playing and not through forcing a child into something. It seems that some practices of reform pedagogy keep the child at an infant level and do not prepare him/her for the world of adults. For Arendt "the function of the school is to teach children what the world is like and not to instruct them in the art of living".

\section{CONCLUSION}

In this paper I have presented the interrelations between practices and discourse and have raised the question of crisis within a Progressive Education teaching situation. In a more general sense focusing on Progressive Education means to implicate a general crisis of schooling. The approach of educational ethnography and its particular elaborations and adoptions of Videography, Schatzkis practice theory and Foucaults concepts of governance, subject and power allows to describe and analyze these crisis' as an institutionalized arrangement of practices and discourses.

While the fact-orientated research (Tatsachenforschung) of Petersen and Müller-Petersen can be seen as a professional tool kit for teachers (here Mr. Meyer) to reflect on their teaching and plan further pedagogical activities to explicitly integrate the pupil (here Zlatko) into the organized teaching arrangement, it is the educational ethnography that enables us to theorize the current pedagogical ordering of the institution.

Through Ethnography we are able to see and analyze the particular bodily expressions that perform the ambivalences of knowing. This means for pupils and teachers to know and to learn how to play, which in the Progressive Education Discourse will transform into knowing how to conduct a conversation. It is this discursive practice of pedagogical governance of the subject within a certain pedagogical order of play and conversation that shall process the possibilities of Bildung for pupils and teachers within Progressive Education arrangements. The interpretation of the given example 
shows that Bildung in its broader idea of transformation and its critic of didactics of (curriculum) learning is a great challenge for educational institution in the twenty-first century. ${ }^{9}$

\section{REFERENCES}

Arendt, H. (1968). The Crisis in Education (1954). In Between Past and Future: Eight Exercises in Political Thought. New York: Penguin.

Biesta, G. (2013). Interrupting the Politics of Learning. Power and Education, 5(1), 4-15.

Bittner, M. (2015). Unterricht machen: Praktiken und Diskurse einer Reformschule. Weinheim: Beltz Juventa.

Bohnsack, R. (2007). Die dokumentarische Methode in der Bild- und Fotointerpretation. In R. Bohnsack, I. Nentwig-Gesemann, \& A.-M. Nohl (Eds.), Die dokumentarische Methode und ihre Forschungspraxis. Grundlagen qualitativer Sozialforschung (2, erweiterte und aktualisierte Auflage, pp. 69-91). Wiesbaden: VS, Verl. für Sozialwiss.

Bohnsack, R., Pfaff, N., \& Weller, W. (Eds.). (2010). Qualitative Analysis and Documentary Method in International Educational Research. Leverkusen: Budrich, Barbara.

Bourdieu, P. (1976). Entwurf einer Theorie der Praxis auf der ethnologischen Grundlage der kabylischen Gesellschaft. Frankfurt am Main: Suhrkamp.

Clifford, J., \& Marcus, G. E. (Eds.). (1986). Writing Culture. Theo Poetics and Politics of Ethnography. Berkeley, Los Angeles, London: University of California Press.

Foucault, M. (1972). The archaeology of knowledge: [by] Michel Foucault. World of man. New York: Pantheon Books.

Foucault, M. (1988). Technologies of the Self. In L. H. Martin, Huck Gutman, \& Patrick H. Hutton (Eds.), Technologies of the Self: a seminar with Michel Foucault (pp. 16-49). London: Tavistock.

Foucault, M. (1991a). Governmentality. In G. Burchell, C. Gordon, \& P. Miller (Eds.), The Foucault Effect. Studies in Governmentality. \%With two lectures by and an interview with Michel Foucault (pp. 87-104). London, Toronto, Sydney, Tokyo, Singapore: Harvester Wheatsheaf.

Foucault, M. (1991b). Politics and the study of discourse. In G. Burchell, C. Gordon, \& P. Miller (Eds.), The Foucault Effect. Studies in Governmentality. \%With two lectures by and an interview with Michel Foucault. London, Toronto, Sydney, Tokyo, Singapore: Harvester Wheatsheaf.

Foucault, M. (1991c). Questions of method. In G. Burchell, C. Gordon, \& P. Miller (Eds.), The Foucault Effect. Studies in Governmentality. \%With two lectures by and an interview with Michel Foucault. London, Toronto, Sydney, Tokyo, Singapore: Harvester Wheatsheaf.

Jones, K. (1983). Beyond Progressive Education. London and Basingstoke: The Macmillan Press.

Knoblauch, H. (2005). Focused Ethnography. Forum Qualitative Sozialforschung / Forum: Qualitative Social Research, 6(3), Art. 44. Retrieved from http://nbn-resolving.de/urn:nbn:de:0114-fqs0503440

\footnotetext{
${ }^{9}$ Once more I would like to point into the direction of Gert Biestas (e.g. 2013) work and his elaborations on, how we need to change the current ideas of teaching, which are represented among marked driven comparative studies.
} 
Knoblauch, H. (2006). Videography. Focused Ethnography and Video-Analysis. In H. Knoblauch, B. Schnettler, \& J. Raab (Eds.), Video Analysis: Methodology and Methods. Qualitative Audiovisual Data Analysis in Sociology (2nd ed., pp. 69-83). Frankfurt am Main, Berlin, Bern, Bruxelles, New York, Oxford, Wien: Peter Lang.

Knoblauch, H., Schnettler, B., \& Raab, J. (2006). Video-Analysis. Methodological Aspects of Interpretative Audiovisual Analysis in Social Research. In H. Knoblauch, B. Schnettler, \& J. Raab (Eds.), Video Analysis: Methodology and Methods. Qualitative Audiovisual Data Analysis in Sociology (2nd ed., pp. 9-26). Frankfurt am Main, Berlin, Bern, Bruxelles, New York, Oxford, Wien: Peter Lang.

Lamberti, M. (2000). Radical Schoolteachers and the Origins of the Progressive Education Movement in Germany, 1900-1914. History of Education Quarterly, 40(1), 22-48.

Müller-Petersen, E. (1951). Kleine Anleitung zur pädagogischen Tatsachenforschung und ihrer Verwendung. Marburg/Lahn: Simons.

Müller-Petersen, E. (1965). Die Methoden der Pädagogischen Tatsachenforschung. In T. Rutt (Ed.), PETER und ELSE PETERSEN. Die Pädagogische Tatsachenforschung (pp. 127-462). Paderborn: Ferdinand Schöningh.

Petersen, P. (1927/1980). Der Kleine Jena-Plan (56. - 60). Weinheim, Basel: Beltz.

Petersen, P. (1963). Führungslehre des Unterrichts (7. Auflage). Braunschweig u.a.: Georg Westermann Verlag.

Reckwitz, A. (2002). Toward a Theory of Social Practices. A Development in Culturalist Theorizing. European Journal of Social Theory, 5(2), 243-263.

Reckwitz, A. (2003). Grundelemente einer Theorie sozialer Praktiken. Eine sozialtheoretische Perspektive. Zeitschrift für Soziologie, 32(4), 282-301.

Reese, W. J. (2001). The Origins of Progressive Education. History of Education Quarterly, 41, 1-24.

Retter, H. (2009). Peter Petersen, John Dewey, die Religion und der Rassismus. https://www.tubraunschweig.de/Medien-DB/allg-paed/dewey-pet-web2.doc

Rouse, J. (2007). Practice Theory. In Stephen Turner \& Mark Risjord (Eds.), pp. 630-681, Handbook of the Philosophy of Science. Vol. 15: Philosophy of Anthropology and Sociology. Dordrecht: Elsevier.

Schatzki, T. R. (2002). The Site of the Social. A Philosophical account of the constitution of social life and change. University Park, Pennsylvania: The Pennsylvania State University Press.

Wagner-Willi, M. (2006). On the Multidimensional Analysis of Video-Data. Documentary Interpretation of Interaction in Schools. In H. Knoblauch, B. Schnettler, \& J. Raab (Eds.), Video Analysis: Methodology and Methods. Qualitative Audiovisual Data Analysis in Sociology (2nd ed., pp. 143-153). Frankfurt am Main, Berlin, Bern, Bruxelles, New York, Oxford, Wien: Peter Lang.

Wulf, C., Althans, B., Audehm, K., Bausch, C., Göhlich, M., Sting, S., \& Zirfas, J. (2010). Ritual and identity: The staging and performing of rituals in the lives of young people. London: Tufnell.

Wulf, C., Bittner, M., Clemens, I., \& Kellermann, I. (2012). Unpacking recognition and esteem in school pedagogies. Ethnography and Education, 7(1), 59-75. 